\title{
The Effectiveness Of Word Card As Media To Improve Students' English Vocabulary
}

\author{
${ }^{1}$ Ndita Fazriani, ${ }^{2}$ Tri Setianingsih, ${ }^{3}$ Edi Firman \\ ${ }^{123}$ Faculty of Culture, Management, and Business, UNDIKMA Mataram \\ Email: trisetianingsih@ikipmataram.ac.id
}

\begin{abstract}
This research was aimed at finding out the effectiveness of word card to improve students' english vocabulary. The subject of this study was 27 students at first grade of SMKN 1 Batulayar. In which consist of 16 males and 11 females. It was classroom action research, each cycle consist of four steps: planning, acting, observing and reflecting. The researcher used observation sheet to find out the activity during learning process and questionnaire to find out students improve in learning vocabulary. From this research, the students could improve their vocabulary by using word card. It proved in the first cycle, the students mean score was 72.7 there were 18 students passing KKM and the percentage was 66.6\%. And it more improved in the second cycle, the students mean score 87.96 , there was all of students passing KKM and the percentage was $100 \%$. Therefore, students become more enthusiastic and they were more active in learning English vocabulary. From those result the writer concludes that word card method is able to improve students' English vocabulary of SMKN 1 Batulayar at first grade is successful.
\end{abstract}

\section{Key words : Word Card, Vocabulary}

Abstrak. Penelitian ini bertujuan untuk menemukan effektifitas dari kartu kata untuk meningkatkan kosa kata bahasa inggris siswa. Subjek dalam penelitian ini berjumlah 27 siswa kelas satu SMKN 1 Batulayar. Dimana berjumlah 16 laki-laki dan 11 perempuan. Ini adalah penelitian tindakan kelas, setiap siklus terdiri dari empat tahap: perencanaan, tindakan, observasi, refleksi. Peneliti menggunakan lembar observasi untuk mengetahui aktifitas yang terjadi selama proses pembelajaran berlangsung dan soal pertanyaan untuk mengetahui peningkatan siswa dalam belajar kosa kata. Dari penelitian ini, siswa dapat meningkatkan kosa kata dengan menggunakan kartu kata. Dapat dilihat pada siklus pertama,skor rata-rata siswa 72.7 dimana ada 18 siswa melewati KKM dan persentase $66.6 \%$. Dan lebih meningkat pada siklus kedua, rata-rata nilai siswa 87.96 dimana semua siswa melewati KKM dan persentase $100 \%$. Selain itu, siswa menjadi lebih antusias dan mereka lebih aktif dalam belajar kosa kata bahasa inggris. Dari hasilnya peneliti menyimpulkan metode word card mampu meningkatkan kosa kata bahasa inggris siswa SMKN 1 Batulayar kelas satu dengan sukses.

\section{Kata kunci : Kartu Kata, Kosa Kata}

\section{INTRODUCTION}

Vocabulary as one of language components is a very important thing besides other language components. Without vocabulary, people can not say anything. People with large vocabulary are more proficient in language skills than people with little vocabulary. Kamil and Hiebert (2005: 3) argue that vocabulary is the set of words for which we know the meaning when we speak or read orally.
As consequence, the important device in a language is word. Vocabulary is defined as a total number of words, which make up a language (Hornby, 1983). In oxford university press, vocabulary is the list of words with their meanings (Oxford University Press, 2003). In this study, vocabulary defined as the list of the words that usually used in our daily life.

Vocabulary is central to English language teaching because without sufficient vocabulary students cannot understand others 
or express their own ideas. Students often instinctively recognize the importance of vocabulary to their language learning. Teaching vocabulary helps students understand and communicate with others in English. To have mastery over vocabulary is much importance because the people judge you by the words you use. Secondly, having a better vocabulary really improves your ability to think.

Therefore they had to memorize and master a lot of vocabularies from the beginning, students must be able to set learning goals that would allow them to use the language in their daily life. Nation (2001: 6) says that the important statements in learning language are the number of words in the language, the number of words known by native speakers and the number of words needed to use the language. As the main element of language, students should learn vocabulary through pictures that belong to certain language and give meaning when we use them. Without having enough vocabulary students are not able to develop their language skills writing, speaking, reading and listening. Based on the problem, Therefore in this researcher used the different method to make students easy to remember vocabulary the researcher interested improving students' vocabulary by media word cards. To master English vocabulary, we had to know what media we can use therefore learning English becomes easy and interesting for the students. According to Kasbolah (1993:56) one of way to make the conducive class is by using media. The word-cards is an interesting media to motivate the students in making communication and to facilitate the students in learning English. By using word-cards the students learn English while see the picture and meaning. However learning English vocabulary through word-cards had an important role for students. Using word card is not only memorizing the word, it is also supplies the words repetition that can be helpful for their memorization. The words are stored longer on their mind than just memorizing the word list. It is also flexible because the words on the cards can be adjusted with student material.
The use of word card in teaching English vocabulary is one of the media to improve the students' skill in learning vocabulary. Miarson (1984) gives the information about media is tool can be used to simulate thought desire of the students. So that, they can be motivated in teaching and learning process.

The present researcher focused in improving students' vocabulary through word cards. The aims of using this test are to find out the effectiveness of word card as media to improve students in English vocabulary. And then the researcher applaying first the researcher divide five groups into one class and a group of at least six students, after that the researcher choose one group to play game Indonesia Pintar in front of the class by using the media word card that the reseacher had prepared. Then they were divided into two groups where three people as a guessing group and three people again as a group give answers with the word 'yes' 'could be' or 'no'. The group that is the guesser will give a clue to his friend about the restaurant equipment, like as breakfast equipment, lunch, evening, dinner, or equipment for heavy and light food.

Related to the problems above the purpose of the study as follow : The study aimed to find out word cars effective to improve students or not in English vocabulary to the first grade students of SMKN 1 Batulayar.

\section{RESEARCH METHOD}

The design of this research is classroom action research (CAR) method with Costello (2003:18) Action Research design. According to Costello (2003:18) the design consists of several cycles, and each learning converse the planning, implementation action, observation, and reflecting. There are some schemes in the classroom action research, as follow:

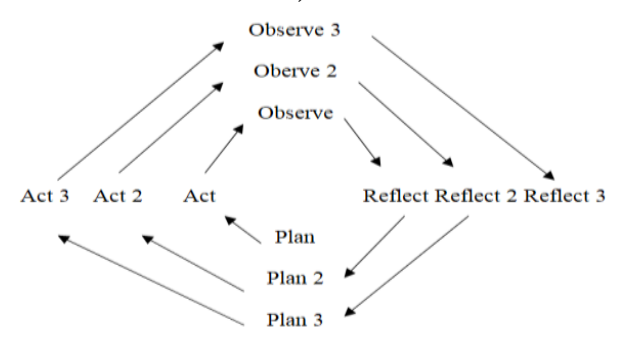

An extended action research model by Costello (2003:18) 


\section{A. Subject of the Study}

The subject of this study is the studentsof first grade students of X-AP at SMKN 1 Batulayar. The object this research is the application of Word-Cards as media to improve students' English vocabulary.

\section{B. Procedure of Action Research}

\section{Lesson Plan Cycle I}

1. Planning

Planning is process to prepare the intructional strategy or technique in order to the problem could be solved that researcher found problem during observation.

- Activities the researcher :

- Prepared teaching aids (word card)

- Preparing the word card about restaurants equipment and designing the steps in doing the action

- Preparing list of students' name and score

- Preparing sheets for classroom observation cheecklist (to know the situation or teaching learning process when the method is applied)

- Preparing a test (to know whether students' vocabulary mastery improve or not).

The researcher made instrument that be used to apply classroom action research such as designing a lesson plan that consist of in cycle I

a. Core Competence : Understanding, applying, analyzing, and evaluating factual, conceptual, basic oprational, and quantifying in accordance with the fields and scope of hotel work.

b. Basic Competence :

- Implementing the use of restaurant appliances.

- Using the tools and restaurant appliances.

c. Learning Objectives :

- Students are able to know the chinaware, silverware, and glassware restaurant equipment, both in hotelss and in independently.

- Students' are able to show what are restaurant equipment it.

d. Learning Material : Restaurant knowledge equipments. e. Teaching Media : Word Card, Textbook, White board, Marker.

f. Learning Methods :

- Scientific Learning

- Technique : Discussion, and question answer game session.

2. Acting

In this phase, both the writer and the teacher collaborated to carry out the plan action,

- Activities researcher are :

- The researcher giving the pre-test firstly.

- Teaching vocabularies using word card method

- Giving the occasion for the students' to ask any difficulties or problem.

- Researcher asking the students several question orally and students have to answer orally.

- Observing the condition in the class when teacher teach students.

- Giving post-tes.

- Teacher activities are :

- Teacher teaching students with a method

- Teacher collaborate with the researcher to teach the students

- Teacher giving the researcher to teach the students with the new method

- Teacher observed the researcher in the teaching learning process.

- Teacher evaluation the researcher in the end of time.

The actions are :

\section{a. Opening}

- Opening greetings with "Good morning everybody. How are you today"? and pray to begin the lesson.

- Checking attendance as an attitude of discipline

- Explaining the lesson materials today "Pengetahuan Peralatan Restoran”.

b. Main Activity

Observing :

- The teacher explained the material in the book.

- Teacher ask students to look at the book. 
- The researcher asking the students several question orally and students have to answer orally.

- Teacher observed the condition in class when teaching learning process.

Asking :

- After looking at the book, the teacher asked the students', "what do they know about restaurant equipment?"

Experimenting :

- The teacher choose two group to start the game using word card.

- The teacher tells students' to guessing picture from a friend.

- The teacher explain the way game works.

Communicating :

- The teacher asks the students' to read the correct answer and tell the which are the right answer and not right.

- The teacher asks students' to give the score for friend's work and give the worksheet back to the owner.

Closing :

- Teacher and students conclude the material.

- Teacher previews the next material.

- Teacher closes the class and greets the students.

3. Observing

While the researcher teaching the students in the classroom, the researcher also observed how the class condition, the media used by teacher in teaching vocabulary in the class and also the researcher observed the students' attention and interest of students in learning vocabulary with the media use by the teacher before the researcher using different method in vocabulary by using word card as the media. In this phase is one of the instruments that used in collecting the data, and observed the teacher teaching and learning process and also the condition in the class when the teacher teaching the students.

4. Reflecting

The last step is evaluating the procedures of teaching and learning process whether it needs to be improved or not in order to get satisfied result. In this step, the researcher makes the summary about the result of observation and the test.

\section{Lesson Plan Cycle II}

1. Planning

Planning is process to prepare the intructional strategy or technique in order to the problem could be solved that researcher found problem during observation.

- Activities the researcher :

- Prepared teaching aids (word card)

- Preparing the word card about restaurants equipment and designing the steps in doing the action

- Preparing list of students' name and score

- Preparing sheets for classroom observation cheecklist (to know the situation or teaching learning process when the teacher teach students)

- Preparing a test (to know whether students' vocabulary mastery improve or not).

The researcher made instrument that be used to apply classroom action research such as designing a lesson plan that consist of in cycle II

f. Core Competence : Understanding, applying, analyzing, and evaluating factual, conceptual, basic oprational, and quantifying in accordance with the fields and scope of hotel work.

g. Basic Competence :

- Implementing the use of restaurant appliances.

- Using the tools and restaurant appliances.

c. Learning Objectives :

- Students are able to know the chinaware, silverware, and glassware restaurant equipment, both in hotelss and in independently.

- Students' are able to show what are restaurant equipment it.

d. Learning Material : Restaurant knowledge equipments.

e. Teaching Media : Word Card, Textbook, White board, Marker.

f. Learning Methods :

- Scientific Learning

- Technique : Discussion, and presentation in front class. 


\section{Acting}

In this phase, both the writer and the teacher collaborated to carry out the plan action,

- Activities researcher are :

- Teaching vocabularies using modify word card method

- Giving the occasion for the students' to ask any difficulties or problem.

- Researcher asking the students several question orally and students have to answer orally.

- Observing the condition in the class when teacher teach students.

- Giving post-tes.

- Teacher activities are :

- Teacher teaching students with a method

- Teacher collaborate with the researcher to teach the students

- Teacher giving the researcher to teach the students with the new method

- Teacher observed the researcher in the teaching learning process.

- Teacher evaluation the researcher in the end of time.

The actions are :

g. Opening

- Opening greetings with "Good morning everybody. How are you today"? and pray to begin the lesson.

- Checking attendance as an attitude of discipline

- Explaining the lesson materials today "Pengetahuan Peralatan Restoran”.

h. Main Activity

Observing :

- The teacher explained the material in the book.

- Teacher ask students to look at the book.

- The researcher asking the students several question orally and students have to answer orally.

- Teacher observed the condition in class when teaching learning process.

Asking :

- After looking at the book, the teacher asked the students', "what do they know about restaurant equipment?"

Experimenting :

- The teacher choose students one by one to presentation about name of restaurant equipment

- The teacher observe the students if missunderstanding about name restaurant equipment

Communicating :

- The teacher asks the students' to read the correct answer and tell the which are the right answer and not right.

- The teacher asks students' to give the score for friend's work and give the worksheet back to the owner.

Closing :

- Teacher and students conclude the material.

- Teacher previews the next material.

- Teacher closes the class and greets the students.

\section{Observing}

While the researcher teaching the students in the classroom, the researcher also observed how the class condition, the media used by teacher in teaching vocabulary in the class and also the researcher observed the students' attention and interest of students in learning vocabulary with the media use by the teacher before the researcher using different method in vocabulary by using word card as the media. In this phase is one of the instruments that used in collecting the data, and observed the teacher teaching and learning process and also the condition in the class when the teacher teaching the students.

4. Reflecting

The last step is evaluating the procedures of teaching and learning process whether it needs to be improved or not in order to get satisfied result. In this step, the researcher modifying the method to find out the students mastery vocabulary about name of restaurant equipment and the researcher makes summary about the result of observation and the test. 


\section{Instrument of Research}

There are two instrument that were in the activity, they are :

a. Observation

In observation, the researcher collected data about students' activity in teaching and learning process. Then observation is given based on reality in the classroom, they typed of observation which is used in this research is direct observation.

b. Test

In test, the researcher gave the students vocabulary test which consist of 20 items about the kinds stemmed glass, unstemmed glass, cutlery (knife), cutlery (spoon) and cutlery (fork). The aims of using this test are to find out the effectiveness of word card as media to improve students in English vocabulary. And then the researcher applaying first the researcher divide five groups into one class and a group of at least six students, after that the researcher choose one group to play game Indonesia Pintar in front of the class by using the media word card that the reseacher had prepared. Then they were divided into two groups where 3 people as a guessing group and 3 people again as a group give answers with the word 'yes' 'could be' or 'no'. The group that is the guesser will give a clue to his friend about the restaurant equipment, like as breakfast equipment, lunch, evening, dinner, or equipment for heavy and light food.

\section{Data Analysis Procedure}

In this research to analyze the data, the researchers observed of students' activity during teaching and learning process. In this case, the researcher analyzing the numerical data, first the researcher tried to get the average of students' vocabulary score per action within one cycle. It used to know how well students' score as a whole on vocabulary skill. It used the formulation as follows:

$$
X=\frac{\sum X}{N}
$$

Where :

$\mathrm{X}=$ The means score of the student

$\Sigma \mathrm{x}=$ The total of student's score

$\mathrm{N}=$ The total number of students
(Fraenkel 2012: 199)

To find out the precentage score of students the researcher used the followingformula :

Where:

$$
P=\frac{F x}{N} X 100 \%
$$

$$
\begin{aligned}
& \mathrm{P}=\text { Percentage } \\
& \mathrm{Fx}=\text { Frequency } \\
& \mathrm{N}=\text { Sample }
\end{aligned}
$$

(AnasSudijono, 2008: 43)

\section{E. Indicator of Success}

Classroom action research (CAR) is succeed if can be exceed the creteria that had been determined and classroom action research call fail it cannot exceed the criteria of score. The score of school minimum passing grade (KKM) of this school is 7,5 where this score adapted from school agreement.

\section{RESEARCH FINDING AND DISCUSSION}

In this chapter, the data consist of pretest, post-test, observation checklist. The data of post-test presented in the improvement of students' achievement in acquiring vocabulary through word card as media. In addition the questionnaire showed the students' interest in vocabulary along the teaching learning process.

\section{A. Result}

The result of Pre-Test was done before the class room action research it was conducted on March 2020. There were 20 questions consisted of vocabulary whitout using word card.

Table 1. The result of students pre-test

\begin{tabular}{|c|c|c|}
\hline No. & Students Name & Pre-Test \\
\hline 1. & MY & 10 \\
\hline 2. & DL & 15 \\
\hline 3. & MSR & 15 \\
\hline 4. & MRA & 15 \\
\hline 5. & RM & 0 \\
\hline 6. & MHH & 20 \\
\hline 7. & RM & 20 \\
\hline 8. & RDJ & 15 \\
\hline 9. & AJY & 15 \\
\hline 10. & J & 15 \\
\hline 11. & RWA & 40 \\
\hline
\end{tabular}




\begin{tabular}{|c|c|c|}
\hline 12. & AS & 25 \\
\hline 13. & R & 30 \\
\hline 14. & KYS & 30 \\
\hline 15. & EW & 25 \\
\hline 16. & DI & 50 \\
\hline 17. & ZI & 50 \\
\hline 18. & LAA & 35 \\
\hline 19. & SL & 40 \\
\hline 20. & NA & 25 \\
\hline 21. & LA & 15 \\
\hline 22. & LS & 20 \\
\hline 23. & SS & 40 \\
\hline 24. & F & 35 \\
\hline 25. & MA & 30 \\
\hline 26. & MS & 30 \\
\hline 27. & IH & 35 \\
\hline & TOTAL & $\mathbf{6 9 5}$ \\
\hline & MEAN & $\mathbf{2 6 , 7}$ \\
\hline
\end{tabular}

Based on the table of the students learning, gained an average of class is 26,7, all of students were not reached yet the target score. Based in the students score in pre-test it show that the criteria of success is not achieved yet or normal score. There were 20 question consist of vocabulary, and all of the students not completed in pre-test were not reached yet the KKM 75.

\section{B. Process Implementing of CAR}

This research consists of two cycles, there were cycle 1 and cycle 2 with 4 phases for each cycle: planning, acting, observing and reflecting.

\section{Cycle I}

a. Planning

In this phase, the writer and teacher planned some instruments they used in the class, the researcher plan the action dealing decided the topic (standard competency and basic competency), that would be deliver to the students by using word card. The researcher prepares the materials and media. As well as prepare the observation checklist which used to look teacher's activities and condition in the class during the teaching and learning process in the classroom. The researcher also prepared post-test to collect the data to know there some students improvement score from pretest to post-test.

b. Acting

In implementation the action, the researcher acted as the teacher in the class, meanwhile the researcher acted as the observer to know the class condition when the teaching and learning process.

1. First meeting

This phase conducted on Thursday, 5 March 2020 at $07.30-09.30$. In the first meeting the lesson start at 07.30 am until $09.30 \mathrm{am}$. The researcher opened the activity by greeting students, and the researcher checking attendance the students to know the students one by one, after that the researcher explain the lesson materials about restaurant knowledge equipments. Before the lesson start, researcher give pre-test to class for about 30 minutes, after the students finish did pre-test, the researcher began to teach vocabulary materials. The researcher told the students "students, today we would study vocabulary with the theme "restaurant knowledge equipment". Then the researcher start the lesson by ask the students to memorized the vocabulary about name of restaurant equipments. In the main activity the researcher implement the teaching learning process of restaurant equipment.The researcher ask the students to know how many vocabulary they can memories in lesson food and beverage. And the researcher introduces the media word card in teaching vocabulary.Then the teacher shown word card to students. After that, the teacher asked the students to remember vocabular about name of restaurant equipment and the teacher give a question to the students one by one and answer orallyuntil time over.

After that the researchers give the students time to memorize the all of name restaurant equipments. The researcher thing the students enjoy with this material because the researcher use the some method to students easy to remember about vocabulary. 
Tabel 2. Students condition in class

\begin{tabular}{|c|c|c|}
\hline No. & Class condition & $\begin{array}{l}\text { Number of } \\
\text { students }\end{array}$ \\
\hline 1. & $\begin{array}{l}\text { Students active in } \\
\text { teaching and } \\
\text { learning process. }\end{array}$ & 7 \\
\hline 2. & $\begin{array}{l}\text { Students involved in } \\
\text { teaching learning } \\
\text { process. }\end{array}$ & 27 \\
\hline 3. & $\begin{array}{l}\text { Students are not } \\
\text { respond. }\end{array}$ & 8 \\
\hline 4. & $\begin{array}{l}\text { Students passive in } \\
\text { the class. }\end{array}$ & 5 \\
\hline 5. & $\begin{array}{l}\text { Students } \\
\text { enthusiastics are } \\
\text { teaching learning } \\
\text { process. }\end{array}$ & 7 \\
\hline
\end{tabular}

1. Based on table above, there are 27 students who follow the learning process, andthen there are a few students who have different characteristics just like there are 7 students active in the learning process taking place by asking, responding and otherwise, there are 8 students not respond when the teaching learning process. In addition, there are 5 students who either Second meeting

This meeting conducted on Saturday, 7 March 2020 at 07.30 - 09.30. The lesson start at 07.30 am until 09.30 am on the second meeting the researcher open the activity by greeting the students and asking their conditions, checking the students' attendant list, and also the researcher gives the students motivation before teaching and learning process. The teaching and learning process in the class room action research was similar with the earlier meeting.

The materials were still same and then the researcher and the students were conducted simulating as the previous meeting.

Teacher : Well students, In this meeting the researcher divided into five group and a group of at least six students, after that the researcher choose one group to play game 'Indonesia Pintar' in front of the class by using the media word card that the researcher had prepared.
Then they will be divide into two groups where 3 people as a guessing group and 3 people again as a group give answers with the word 'yes' 'could be' or 'no'. The group that is the guesser will give a clue to his friend about the restaurant equipment, like as breakfast equipment, lunch, evening, dinner, or equipment for heavy and light food.

Students : group 1, as a guessing group and this group just guess about the picture word card available in versus group.

Group 2, as the answer group with the word 'yes' or 'no' and 'could be'.

In the main activity the researchers try to implement the teaching learning process of restaurant equipment using the method word card. At the end of lesson, the researcher give the conclusion about the lesson today with the word card as media and the researcher get the result from students, they can get moreknowledge about vocabulary, moreover students easy to remember about vocabulary and enjoy with the lesson with the some method, after that the researcher close the meeting.

\section{Tabel 3. Students condition in class}

\begin{tabular}{|c|c|c|}
\hline No. & Class condition & $\begin{array}{l}\text { Number of } \\
\text { students }\end{array}$ \\
\hline 1. & $\begin{array}{l}\text { Students active in } \\
\text { teaching and learning } \\
\text { process. }\end{array}$ & 7 \\
\hline 2. & $\begin{array}{lr}\text { Students } & \text { involved in } \\
\text { teaching } & \text { learning } \\
\text { process. } & \end{array}$ & 27 \\
\hline 3. & $\begin{array}{l}\text { Students are not } \\
\text { respond. }\end{array}$ & 3 \\
\hline 4. & $\begin{array}{l}\text { Students passive in } \\
\text { the class. }\end{array}$ & 6 \\
\hline 5. & $\begin{array}{lr}\text { Students } & \text { are } \\
\text { enthusiastics } & \text { in } \\
\text { teaching } & \text { learning } \\
\text { process. } & \end{array}$ & 11 \\
\hline
\end{tabular}

Based on the result table above, the little changes from tbe students were not responding, there were 27 students who follow the teaching learning process, then there were 7 students active in teaching learning process by asking, 
responding, etcetera. Otherwise, there were students not responding when teaching learning process different from the first meeting. And this day very different from the previous meeting this time there were 11 students enthusiastic about the material today because students interested with the method used by teacher.

Tabel 3.1 Score Affective Students

\begin{tabular}{|c|c|c|c|c|c|c|}
\hline No. & Score Affective & $\begin{array}{c}\text { Very } \\
\text { Often }\end{array}$ & Often & $\begin{array}{c}\text { Getting } \\
\text { Spotted }\end{array}$ & Sparse & Never \\
\hline 1. & Exact & & & $\mathbf{3}$ & & \\
\hline 2. & Be Responsible & & & & $\mathbf{2}$ & \\
\hline 3. & Collaborate & & $\mathbf{4}$ & & & \\
\hline 4. & $\begin{array}{c}\text { Ative In } \\
\text { Learning }\end{array}$ & & & $\mathbf{3}$ & & \\
\hline 5. & Attention & & & $\mathbf{3}$ & & \\
\hline 6. & Manner & & & $\mathbf{3}$ & & \\
\hline
\end{tabular}

Keterangan :

- SS (Sangat Sering $)=5$

- SR (Sering) $=4$

- ML (Mulai Terlihat) $=3$

- JR (Jarang) $=2$

- TP $($ Tidak Pernah $)=1$

1. Third meeting

On Thursday, 12 March 2020 at 07.30

- 09.30. In third meeting as usual the researcher had been ready in the class room, the main activity same like the previous meeting, the researcher continued the remains groups of students to run activity. The researcher also asked the students who still remember about vocabulary we learn in the previous meeting, and gave the students motivated before the researcher continue the teaching and learning process.

In the last meeting in cycle $\mathrm{I}$, the researcher closed activity asked the students' difficulties during teaching and learning process and the researcher gave the post-test to the students to know the students ability after implemented teaching and learning process by using word card as media in teaching vocabulary.

Andthen the researcher wrote down/ observation what happened in the classroom or students' activity during the learning process.
Table 4. Observation Checklist (McPheat 2011: 11) in the cycle $I$

\begin{tabular}{|c|l|c|c|}
\hline No. & \multicolumn{1}{|c|}{ Observed Aspect } & YES & NO \\
\hline 1 & Teacher greets and invites the students to pray & V & \\
\hline 2 & Teacher checking the attendence list & V & \\
\hline 3 & $\begin{array}{l}\text { Teacher give information about the material to be } \\
\text { taught that is "Pengetahuan Peralatan Restoran" }\end{array}$ & V & \\
\hline 4 & Teacher give phase learning activity to the end & & V \\
\hline 5 & $\begin{array}{l}\text { Teacher observe students during teaching learning } \\
\text { process }\end{array}$ & & V \\
\hline 6 & $\begin{array}{l}\text { Teacher give the opportunity for students to ask } \\
\text { some question }\end{array}$ & V & \\
\hline 7 & $\begin{array}{l}\text { Teacher try to give a sample of the materia in the } \\
\text { book }\end{array}$ & V & \\
\hline 8 & $\begin{array}{l}\text { Teacher give students a sample material about } \\
\text { name of restaurant equipment }\end{array}$ & & V \\
\hline 9 & Teacher give the students discuss together & & V \\
\hline 10 & Teacher give students question to work & V & \\
\hline
\end{tabular}

\section{Observing}

The researchers did the observation on teaching and learning process in cycle I showed the result of teacher and students' observation.

- Teacher observation results :

Teacher always give greet and invite students to pray together when they begin the learning process, teacher do not extend the stages of learning activity so that students sometimes finish their assignments straight out of class, and teacher also lack to observe students when the teaching learning process so that why students become unwilling to learn.

- Students observation results :

Were mentioning restaurant equipment and students understand the material that teacher have taught and otherwise students can anaylze the form of restaurant equipment and mention the name in English.

Students could complete the test multiple choices timely, students very happy with the method used, and students became more active in the classroom such as asking and having more curiosity to understand it moreover students became more diligent in the class.

Students could distinguish the name of restaurant equipment, students could also be more familiar with the restaurant equipment because the students see the picture in word card and students can properly name the restaurant equipment in English.

After teaching and learning process was finished, the researcher gave students evaluation post-test with the model test is 
multiple choice vocabularies in the next meeting to know the students' ability after study by using word card.

Here, the researcher found that some students were enthusiasm in receiving new vocabulary, they proudly asked teacher in English language even though in the very simple question. Then the researcher gave them point, it was for encouraging them to participate during the English class.

3. Reflecting

After doing all of the phases were finished the researcher got the result of students' evaluation (post-test).

Here is the table of students' score post test1 :

Table 5. Students' score post-test 1

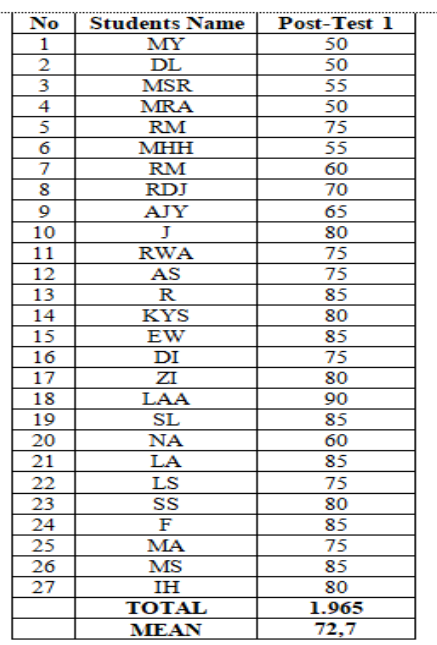

In the first cycle, there were only nine students had passed KKM the researcher found so many students had not reached it yet. The researcher and the teacher evaluate why so many students still could not pas KKM, based on the observation, the researcher found that some students did not pay attention and not really understand during the class.

From those problems, the researcher and the teacher decided to carry out the second cycle. In the second cycle, they still used word card as media, however they make the class more interesting than in the previous cycle, the researcher made the game "Indonesia Pintar" beside to make students more interesting in the classroom activity and the game also was given students to reinforce their memorization.

\section{Cycle II}

a. Planning
In the first cycle, the researcher found so many students had not reached KKM. In this stage on Thursday, 26 March 2020, for the cycle the researcher rearranged the lesson plan based on the reflecting in phase in the first cycle. The lesson plan was related to using word card as media but there were some modification. The researcher and the teacher discussed on the problem then found the solution to solve the problem. The researcher makes the class more interesting for the students and more enthusiastic in receiving new vocabulary.

In this cycle, the researcher prepares some new vocabulary gave to the students, the vocabularies were still from their book, and the researcher also prepares to modifying the method.

b. Acting

1. This phase, the researcher conducted teaching and learning activities to get the better result than the first cycle. First meeting

On Friday, 27 March 2020 at $07.30-09.30$, the researcher reviews all of the vocabulary about name of restaurant equipment that is to make the students remember that. In this second cycle the researcher, modify the action based upon the several problems faced by students in the first cycle to make them more pleasant and can encourage students to remember them more quickly.

In the main activity the researcher implement the teaching learning process of restaurant equipment appliances by modifying the game word card.

At the end of the lesson, the researcher gave the conclusion about the lesson that has been given, and the researcher closed the meeting.

\section{Tabel 6. Students condition in class}

\begin{tabular}{|c|l|c|}
\hline No. & \multicolumn{1}{|c|}{ Class condition } & $\begin{array}{c}\text { Number of } \\
\text { students }\end{array}$ \\
\hline 1. & $\begin{array}{l}\text { Students active in teaching and } \\
\text { learning process. }\end{array}$ & 7 \\
\hline 2. & $\begin{array}{l}\text { Students involved in teaching } \\
\text { learning process. }\end{array}$ & $\mathbf{2 5}$ \\
\hline 3. & Students are not respond. & $\mathbf{1}$ \\
\hline 4. & Students passive in the class. & $\mathbf{3}$ \\
\hline 5. & $\begin{array}{l}\text { Students are enthusiastics in } \\
\text { teaching learning process. }\end{array}$ \\
\hline
\end{tabular}

From the table above, there are 25 students who follow the teaching learning 
process, then there were seven students active in the learning process like active questioning, and there is only one students who did not respond teaching learning process. In addition there were three who are passive or not care during class, So, in here we can see very different from the previous meeting and the last one real different from the previous meeting and this time it looks more good there were 14 students enthusiastics with the lesson today.

\section{Tabel 6.1 Score Affective Students}

\begin{tabular}{|c|c|c|c|c|c|c|}
\hline No. & Score Affective & $\begin{array}{c}\text { Very } \\
\text { Often }\end{array}$ & Often & $\begin{array}{c}\text { Getting } \\
\text { Spotted }\end{array}$ & Sparse & Never \\
\hline 1. & Exact & & & $\mathbf{3}$ & & \\
\hline 2. & Be Responsible & & & $\mathbf{3}$ & & \\
\hline 3. & Collaborate & $\mathbf{5}$ & & & & \\
\hline 4. & $\begin{array}{c}\text { Ative In } \\
\text { Learning }\end{array}$ & & $\mathbf{4}$ & & & \\
\hline 5. & Attention & & & $\mathbf{3}$ & & \\
\hline 6. & Manner & & & $\mathbf{3}$ & & \\
\hline
\end{tabular}

Keterangan :

- SS $($ Sangat Sering $)=5$

- SR (Sering) $=4$

- ML (Mulai Terlihat) $=3$

- JR (Jarang) $=2$

- TP $($ Tidak Pernah $)=1$

2. Second meeting

In this phase on Saturday, 28 March 2020 at 07.30 - 09.30. The researcher choose one of the students based on the attendance list to present in front of class with the picture word card on the table, after that the students say to friends about what its name of equipment on the word card, if students answer wrong they get punishment like crossed out with marker.

In the main activity the researcher implemented the teaching learning process of restaurant equipment appliances by modifying the game word card.

After finishing the process, the researcher reviewed the materials in the previous meeting and after that the researcher asked the students about this lesson today because the researcher modification the game to make the students brush up with the memorization in the previous meeting, and to make the students easy to remember that, and then the researcher close the meeting today.
Tabel 7. Students condition in class

\begin{tabular}{|c|l|c|}
\hline No. & \multicolumn{1}{|c|}{ Class condition } & $\begin{array}{c}\text { Number of } \\
\text { students }\end{array}$ \\
\hline 1. & $\begin{array}{l}\text { Students active in teaching and learning } \\
\text { process. }\end{array}$ & $\mathbf{1 1}$ \\
\hline 2. & $\begin{array}{l}\text { Students involved in teaching learning } \\
\text { process. }\end{array}$ & $\mathbf{2 7}$ \\
\hline 3. & Students are not respond. & $\mathbf{2}$ \\
\hline 4. & Students passive in the class. & $\mathbf{1}$ \\
\hline 5. & $\begin{array}{l}\text { Students are enthusiastics in teaching learning } \\
\text { process. }\end{array}$ & $\mathbf{1 3}$ \\
\hline
\end{tabular}

Based the table above, there were changes coming from active, enthusiastic students in teaching learning process. In conclusion the students who follow the teaching learning process 27 students and is divided into students still active increasing from earlier to 11 students, 2 unresponsive students, and there was only one students passive in the teaching learning process and 13 students enthusiastic in teaching learning process.

Tabel 7.1 Score Affective Students

\begin{tabular}{|c|c|c|c|c|c|c|}
\hline $\begin{array}{c}\text { No } \\
\cdot\end{array}$ & $\begin{array}{c}\text { Score } \\
\text { Affective }\end{array}$ & $\begin{array}{c}\text { Very } \\
\text { Often }\end{array}$ & Often & $\begin{array}{c}\text { Getting } \\
\text { Spotted }\end{array}$ & Sparse & Never \\
\hline 1. & Exact & & & $\mathbf{3}$ & & \\
\hline 2. & Be Responsible & & $\mathbf{4}$ & & & \\
\hline 3. & Collaborate & $\mathbf{5}$ & & & & \\
\hline 4. & $\begin{array}{c}\text { Ative In } \\
\text { Learning }\end{array}$ & & $\mathbf{4}$ & & & \\
\hline 5. & Attention & $\mathbf{5}$ & & & & \\
\hline 6. & Manner & & $\mathbf{4}$ & & & \\
\hline
\end{tabular}

Keterangan :

- SS $($ Sangat Sering $)=5$

- SR (Sering) $=4$

- ML (Mulai Terlihat) $=3$

- JR (Jarang) $=2$

- TP $($ Tidak Pernah $)=1$

3. Third meeting

This the last meeting of cycle II conducted on Tuesday, 31 March 2020 at 09.30 - 12.00. As usual, the researcher greeted the students and checked the attendance list before continued the lesson. After that the researcher gave the post-test to the students to know the students ability after implemented teaching and learning process of restaurant equipment appliances by modifying the game word card in teaching vocabulary.

In this cycle also, the researchers started to observe teacher activity during teaching and learning process. The result of observation was show in the table below: 
Table 8. Observation checklist (McPheat 2011: 11) in the cycle II

\begin{tabular}{|c|c|c|c|}
\hline No. & Observed Aspect & YES & NO \\
\hline 1 & $\begin{array}{l}\text { Teacher greets and invites the students to } \\
\text { pray }\end{array}$ & $\mathrm{V}$ & \\
\hline 2 & Teacher checking the attendence list & $\mathrm{V}$ & \\
\hline 3 & $\begin{array}{l}\text { Teacher give information about the } \\
\text { material to be taught that is "Pengetahuan } \\
\text { Peralatan Restoran" }\end{array}$ & $\mathrm{V}$ & \\
\hline 4 & $\begin{array}{l}\text { Teacher give phase learning activity to } \\
\text { the end }\end{array}$ & & $\mathrm{V}$ \\
\hline 5 & $\begin{array}{l}\text { Teacher observe students during teaching } \\
\text { learning process }\end{array}$ & $\mathrm{V}$ & \\
\hline 6 & $\begin{array}{l}\text { Teacher give the opportunity for students } \\
\text { to ask some question }\end{array}$ & $\mathrm{V}$ & \\
\hline 7 & $\begin{array}{c}\text { Teacher try to give a sample of the } \\
\text { materia in the book }\end{array}$ & & $\mathrm{V}$ \\
\hline 8 & $\begin{array}{l}\text { Teacher give students a sample material } \\
\text { about name of restaurant equipment }\end{array}$ & $\mathrm{V}$ & \\
\hline 9 & $\begin{array}{l}\text { Teacher give the students discuss } \\
\text { together }\end{array}$ & $\mathrm{V}$ & \\
\hline 10 & Teacher give students question to work & $\mathrm{V}$ & \\
\hline
\end{tabular}

c. Observing

The researcher with the English teacher carried out the observation. Both of them observed the teaching process by monitoring the students' activity and teacher activity in this cycle. This observation was done to get the data of students' and teacher progress during the teaching and learning process.

- Teacher observation results :

Teacher built students competence for knowledge of restaurant equipment, teacher also illustrate the restaurant's equipment by word card method and students feel more enthusiastic about attending the lesson, as well as teacher give a test multiple choice to the students.

- Students observation results :

Were mentioning the name of restaurant equipment and students understand the material that teacher have taught and otherwise students can anaylze the form of restaurant equipment and mention the name in English. It could be said that the majority of the students join the class enthusiastically. Students were more active in the class. It was proved by all the students during the teaching and learning process in the class. All activity in the cycle II could run well while teaching and learning process of word card.

Students can complete the test multiple choices timely, students very happy with the method used, and students are more active in the classroom such as asking and having more curiosity to understand it moreover students become more diligent in the class.
Students could distinguish the name of restaurant equipment, students can also be more familiar with the restaurant equipment because the students see the picture in word card and students can properly name the restaurant equipment in English.

In the first cycle, the researcher found the students still had bad memorization when they were asked to recall the words they only could remember a few words. However, in this cycle the researcher got students had better enthusiasm, many students were brave to give the English teacher question and they actively respond the teacher's, and class was more interesting and communicative. In this first cycle the researcher asked students to guess the picture in word card, but now the researcher asked the students to presented the all of name about restaurant equipment.

d. Reflecting

In this second cycle, students were better than in the first cycle, it was shown by students' capability to recall the name of restaurant equipment and their meaning. In addition, they got the better score than the first cycle. Below is the score students' post-test in cycle II:

Table 9. Students' score post-test 2 :

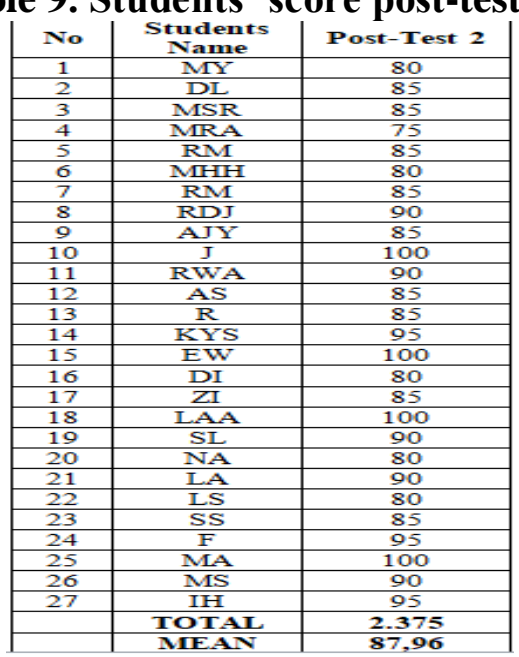

In this cycle, the students get better score, the mean also improved from 72 to 87 . This cycle showed the highest improvement related to the students interest toward vocabulary in learning process by using word card different in 
first cycle the students interest in English were low.

Table 9.1. Comparison between score posttest 1 and post-test 2

\begin{tabular}{|c|c|c|c|c}
\hline No & $\begin{array}{c}\text { Students } \\
\text { Name }\end{array}$ & $\begin{array}{c}\text { Post- } \\
\text { Test }\end{array}$ & $\begin{array}{c}\text { Post- } \\
\text { Test } \\
\mathbf{1}\end{array}$ & $\mathbf{2}$ \\
\hline 1 & MY & 50 & 80 & $=\frac{X}{N}$ \\
& $=\frac{1.965}{27}$ \\
& $=72,7 \%$
\end{tabular}

Where: $X=$ the means score of the students

$\mathrm{Ex}=$ the total of students' score

$\mathrm{N}=$ the total number of students

(Fraenkel 2012: 199)

In this data analysis the result students' score towards ability in learning vocabulary, it show that the students who get the highest score on cycle 1 were some of the students with their score 90, some of students get the lowest score 50 . In this cycle 1 there are 8 students nothing pasing KKM, and why did this happen because there are some students still low participation and limited the knowledge about vocabulary, the students interest with this method because make students easy to remember vocabulary by using a method. Therefore, in this cycle we can know students need something to make they interest or have fun in the learning andthen we can see the different score when the researcher use method and not using method.

The next step was calculating the percentage of students passing KKM in post-test 2 . In this test, all of students could reach KKM.

$$
\begin{aligned}
& \mathrm{P}=\frac{F}{N} X 100 \% \\
& =\frac{27}{27} \times 100 \% \\
& =100 \%
\end{aligned}
$$

Where: $\mathrm{P}=$ Percentage

$$
\begin{aligned}
& \mathrm{F}=\text { Frequency } \\
& \mathrm{N}=\text { Sample }
\end{aligned}
$$

(AnasSudijono, 2008: 43)

The result of the test tabulated to find out the means score:

$$
\begin{aligned}
\mathrm{X} & =\frac{\Sigma X}{N} \\
& =\frac{2.375}{27} \\
& =87,96 \%
\end{aligned}
$$

Where: $X=$ the means score of the students 
$\Sigma \mathrm{x}=$ the total of students' score

$\mathrm{N}=$ the total number of students

(Fraenkel 2012: 199)

In this cycle we had better score from the first cycle and why did this happen because in this cycle the researcher try to modify the method to make students better than ever and students in this cycle more enthusiastic in teaching and learning process, and the researcher see the students more active in the learning process and they very interest with the method that do not bore them to play while studiying. Therefore all of the students get the passing KKM, and this cycle we called success.

\section{Discussion}

Based on the data above where in post-test 1 , it was conducted in the first cycle of CAR Costello (2003:18), the mean of students' score was 72 the percentage of students get 75 or above was $66,6 \%$. In the post-test 2 , the mean of the students score improved, it was 87 and the percentage of students get 75 or above was $100 \%$, there were all of 27 students passing KKM. It means this CAR is called successful, because the percentage of students passing KKM was $100 \%$.

In line with the result above, the researcher also found the students' improvements in class, as long as conduct word card as media in teaching vocabulary(Rod Ellis 2008: 263).

In this cycle II, the students get better score, the mean also improved from 72 to 87 . This cycle show the highest improvement related to the students interest toward vocabulary in learning process by using word card different in first cycle the students interest in English were low. Although the students score in the first cycle is good but refers to the students' interest, participation still low, so the researcher continued to the next cycle. After having second cycle which was done by several modified activity the students interest, this fact was also supported by result in second cycle by using word card as media in teaching vocabulary the students' interest and make students improve in vocabulary (Long, M \& Robinson 1998:15).
Based on the result in cycle II the researcher could maximize the time and complete the material so the researcher decided to stop the cycle.

\section{CONCLUSION AND SUGGESTION Conclusion}

Finally after Analyze the data, the researcher found that students who were taught by using word card get higher score than those students were not. From all of the discussion of this thesis, the researcher concludes that using word card is one of the ways to improve students' vocabulary that is helpful students need to improve their vocabulary since vocabulary is one of the most important components in languages, here the researcher conducted research at SMKN 1 Batulayar.

From this research, the researcher found that using word card is good way to be applied in SMKN 1 Batulayar, it was proved by the score that the students have got. In pretest, there is nothing students get passing $\mathrm{KKM}$ it was different with the post-test one, which the students passing KKM were 18 students and the percentage $66.6 \%$. Then it improved in the second cycle, in post-test two the students passing KKM were 27, the percentage was $100 \%$. It means this research is successful, since the criteria of action success is $75 \%$ for the percentage of the students passing KKM. Based on the result of the research, word card has positive effect to improve the students in vocabulary of English at the first grade students of SMKN 1 Batulayar.

\section{Suggestion}

Based on conclusion above, the researcher would like to offer some suggestions for teachers, students, and next researcher. For students, the researcher hopes that the students participation more actively in the classroom, the researcher suggests that every students should have an English dictionary in order to help them tofind out the meaning of difficult word.

For the teacher, the teacher has to make new innovation in teaching especially for teaching vocabulary, so the students do not feel bored, the teacher should make the students interest to learn English and also the 
teacher can create a fun condition in the class, such as one of the appropriate media that the teacher can use in teaching vocabulary.

For the next researcher, the researcher hopes that the result of this research is useful for the those who are interested in English and for those who wants to conduct futher research about the effectiveness of word card as media to improve students English vocabulary.

\section{EFERENCES}

Costello, Patrick J. M. 2003. Action Research. New York: Continuum.

Frankel R.J., Wallen E. Norman, Hyun H. Helen,. 2012. How to Design and Evaluate Research in Education. New York: McGraw-Hill.

Harmer. 1991. The Practice of Language Teaching. New Edition. New York: Longman Publishing.

Hornby, 1995.Oxford Learner Dictionary of Current English. London: Oxford University Press.

J. Wallace. 1982. Action Research for Language Teaching. Cambridge: Cambridge University Press.

J.Wallace. 1982. Teaching Vocabulary. London: Longman Group.

Kamil, M.L. \& Hiebert, E.H. 2005.Teaching and Learning Vocabulary. Bringing Research to Practice. New Jersey: Lawerence Erllbaum Associates.

McCarty, Michel. 1997. Vocabulary Description, Acquisition, and Pedagogy. Cambridge: Cambridge University Press.

Robinson, 1998. Focus on Form Instruction in Classroom Second Language Acquisition. Cambridge: Cambridge University Press.

Roimiszowki. 1981. Teaching Media Suyanto, PT BumiAksara.

Sudijono, Anas, 2003. Pengantar Statistic Pendidikan, Jakarta: Raja Grafindo Persada

Thornbury, S. 2002. How to Teach Vocabulary. London: Longman Group. 